\title{
Relationship Between Cellulolytic Activity and Adhesion to Cellulose in Ruminococcus albus
}

\author{
By E. JANE MORRIS* AND OWEN J. COLE \\ Anaerobic Microbiology Division, Laboratory for Molecular and Cell Biology, Council for \\ Scientific and Industrial Research, Pritate Bag X3, Onderstepoort 0110, South Africa
}

(Received 8 September 1986; revised 18 November 1986)

\begin{abstract}
Bacterial adhesion to cellulose was measured for 13 cellulolytic and 10 non-cellulolytic, xylanutilizing strains of the ruminal bacterium Ruminococcus albus. Radiolabelled bacteria adhering to Whatman CF1l cellulose powder were determined. Adhesion of the cellulolytic strains ranged from 0 to $49 \%$ of the added bacteria. Of the non-cellulolytic strains, 9 showed $<1 \%$ adhesion, while one strain gave $5 \%$ adhesion. For the cellulolytic strains filter paper solubilization ranged from 24 to $100 \%$, while solubilization of CF11 cellulose varied from 0 to $20 \%$. Both cellulolytic and non-cellulolytic strains produced carboxymethylcellulase (CMCase) activity. SDS-PAGE of cell extracts followed by incubation with a gel overlay containing CMC or xylan produced a zymogram of hydrolytic enzyme activity. The cellulolytic strains showed a number of bands of CMCase and xylanase activity. Non-cellulolytic strains possessed fewer bands of activity towards both CMC and xylan. Certain of the enzymes appeared to possess both CMCase and xylanase activity. Bacterial cell surface hydrophobicity was also measured, but no correlation was found between hydrophobicity and adhesion to cellulose.
\end{abstract}

\section{INTRODUCTION}

In a continuous flow ecosystem such as the rumen, bacteria which attach to and colonize solid digesta have a distinct advantage in a competitive environment. The solid digesta are retained in the rumen for longer than the liquid fraction of the rumen contents, and organisms attached to the solid particles are therefore able to maintain their numbers at a lower growth rate. In addition, adherent fibre-digesting bacteria can bring cell-bound enzymes into contact with their substrate, thereby ensuring effective digestion and enabling the degradation products to be immediately available to the bacteria concerned.

Adhesion may be especially important where the digestion of a complex substrate such as a plant cell wall or cellulose is involved, since a number of enzymes must act in combination. When bacteria adhere to the substrate, a complex of enzymes located on the bacterial cell surface can be presented to the substrate in an optimal configuration. Such a complex, consisting of both enzymes and specific adhesion proteins, known as a 'cellulosome' has been proposed for the cellulolytic (non-ruminal) organism Clostridium thermocellum (Bayer et al., 1983; Lamed et al., 1983; Bayer et al., 1985). Such adhesion proteins or 'adhesins' could impart a degree of specificity to the adhesion reaction. For instance, it is known that certain rumen bacteria adhere preferentially to particular types of plant cell wall (Latham et al., 1978). In contrast, less refractory types of cell wall can be degraded by soluble enzymes without the need for adhesion (Akin et al., 1974; Akin, 1980).

Ruminococcus albus is one of the most important cellulolytic rumen bacteria, and has been shown to adhere to cellulose fibres (Patterson et al., 1975; Minato \& Suto, 1978) by a mechanism which is inhibited by various soluble cellulosic derivatives (Minato \& Suto, 1978). However, it

Abbreviation: CMC, carboxymethyl cellulose. 
has not been determined to what extent adhesion is a prerequisite for cellulolysis by this organism and whether adhesion is mediated by particular cellulolytic enzymes. The existence of a group of non-cellulolytic strains of $R$. albus isolated in this laboratory (van der Toorn \& van Gylswyk, 1985) has made possible a comparative study of the adhesion properties and enzyme profiles of cellulolytic and non-cellulolytic strains.

\section{METHODS}

Bacteria. Ruminococcus albus cellulolytic strains X10C33, X10C56, X3D54, X6D60 and X12D62, as well as the non-cellulolytic strains X2A57, X7A62, X5C54, X10C62, X9C63, X6D34, X6D38, X9D54, X8D60 and X6E39, were obtained from the rumens of sheep fed maize straw diets (van der Toorn \& van Gylswyk, 1985). These strains were all isolated on the basis of their ability to degrade xylan, and were maintained on xylan agar slants.

Of the other cellulolytic strains of $R$. albus, 22.08.6A and 21.09.6E were described by Kistner \& Gouws (1964), Ce 54 and Ce 63 by Shane et al. (1969) and strain 30 by van Gylswyk and Roché (1970). Strain AcTF 10 was isolated by Henning (1979) and was extensively characterized by Morris \& van Gylswyk (1980), who also gave microscopic evidence of its attachment to plant cell walls. Strains 7 and 20 were a gift from M. P. Bryant, University of Illinois, Urbana-Champaign, USA, and were positive when tested for visual disintegration of filter paper (Bryant $e t$ al., 1958). All these strains were maintained on cellobiose agar slants. Bacteroides succinogenes $\mathrm{S}-85$ and Ruminococcus flavefaciens FD-1 were gifts from M. P. Bryant.

Culture techniques. Procedures for obtaining and maintaining strictly anaerobic conditions were as described by van Gylswyk \& Hoffmann (1970).

Culture conditions. For measurement of adhesion and determination of hydrophobicity, the bacteria were grown in a liquid medium based on medium 10 of Caldwell \& Bryant (1966) with $0.3 \%$ cellobiose as carbon source and a gas phase containing $30 \%(\mathrm{v} / \mathrm{v}) \mathrm{CO}_{2}, 65 \%(\mathrm{v} / \mathrm{v}) \mathrm{N}_{2}$ and $5 \%(\mathrm{v} / \mathrm{v}) \mathrm{H}_{2}$. For other purposes a medium supplemented with 30 or $40 \%(\mathrm{v} / \mathrm{v})$ rumen fluid (clarified by centrifugation at $13000 \mathrm{~g}$ for $1 \mathrm{~h}$ ) was used, with either cellobiose or cellulose as carbon source, and $95 \%(\mathrm{v} / \mathrm{v}) \mathrm{CO}_{2} / 5 \%(\mathrm{v} / \mathrm{v}) \mathrm{H}_{2}$ in the gas phase.

Cellulose degradation. The ability of the various bacterial strains to solubilize cellulose was determined as described by Morris \& van Gylswyk (1980) with minor modifications. Inocula were grown on cellobiose agar slants. Cellulose substrates (Whatman no. 6 filter paper, ball-milled and freeze-dried, or Whatman CF11 cellulose powder) were used at a $1 \%(\mathrm{w} / \mathrm{v})$ concentration. Bacteria were inoculated into $10 \mathrm{ml}$ culture medium containing the cellulose, and incubated at $39^{\circ} \mathrm{C}$ for $7 \mathrm{~d}$, after which the remaining cellulose was washed on a sintered glass filter, dried, and determined gravimetrically.

Assay for carboxymethylcellulase (CMCase) production. CMCase activity produced by colonies growing on cellobiose agar plates was detected using the Congo red plate technique of Teather \& Wood (1982).

Measurement of adhesion to cellulose. Cells were radiolabelled by the addition of an aqueous solution (37 MBq ml${ }^{-1}$ ) of sodium $\left[1^{-14} \mathrm{C}\right]$ acetate (Amersham, $2 \mathrm{GBq} \mathrm{mmol}^{-1}$ ) to the culture medium to give a final concentration of $37 \mathrm{kBq} \mathrm{ml}^{-1}$. Bacteria were grown to stationary phase in the presence of the radionuclide, then harvested and washed three times with a mineral buffer containing $1.3 \mathrm{mM}-\mathrm{KH}_{2} \mathrm{PO}_{4}, 1.7 \mathrm{mM}-\mathrm{K}_{2} \mathrm{HPO}_{4}, 3.4 \mathrm{mM}-$ $\left(\mathrm{NH}_{4}\right)_{2} \mathrm{SO}_{4}, 0.76 \mathrm{~mm}-\mathrm{NaCl}, 0.38 \mathrm{~mm}-\mathrm{MgSO}_{4}$ and $0.41 \mathrm{~mm}-\mathrm{CaCl}_{2}, \mathrm{pH} 7.0$. These salts were used at the same concentration as supplied in the culture medium. The cells were harvested and washed aerobically except where specified.

The washed cells were resuspended to give an optical density at $660 \mathrm{~nm}$ of $2.0\left(0.54 \mathrm{mg}\right.$ dry weight $\left.\mathrm{ml}^{-1}\right)$, determined by appropriate dilution. The cell suspension was then added to a glass scintillation vial containing $100 \mathrm{mg}$ cellulose (Whatman CF 11 ) which had been previously washed twice in distilled water $(20 \mathrm{ml})$ and once in the mineral buffer $(20 \mathrm{ml})$ to remove fines. Excess liquid was removed each time by aspiration after leaving the cellulose to settle for $5 \mathrm{~min}$.

The cell suspension was gently shaken with the cellulose for $30 \mathrm{~min}$ at room temperature, after which the mixture was diluted by addition of $20 \mathrm{ml}$ mineral buffer. After leaving the cellulose to settle for $5 \mathrm{~min}$ the supernatant was removed by aspiration. The cellulose was washed twice more with buffer in the same way. Scintillation fluid $(10 \mathrm{ml})$ was then added to the washed cellulose, and radioactivity was measured on a scintillation counter. Determinations were done in triplicate, and control vials containing no cellulose were included to measure adhesion to the vial itself and to allow for any clumps of bacteria which might settle from suspension although they were not in fact adherent.

To examine the influence of anaerobic conditions on adhesion, cells were harvested, washed and mixed with cellulose under an atmosphere of $30 \% \mathrm{CO}_{2} / 65 \% \mathrm{~N}_{2} / 5 \% \mathrm{H}_{2}$ in an anaerobic cabinet. The mineral buffer was made up with oxygen-free water, and pre-equilibrated with the anaerobic gas mixture before adjustment of $\mathrm{pH}$. In some instances $1 \mathrm{mM}$-dithiothreitol was added to the buffer. Paraliel experiments were done under aerobic conditions for comparison.

Solubilization of $R$. albus cells. The cells of $R$. albus were resistant to the action of lysozyme, but could readily be solubilized by mutanolysin (Sigma). Bacteria grown in rumen fluid medium with $0.5 \%$ cellobiose were harvested by centrifugation, washed twice in mineral buffer, and resuspended in $20 \mathrm{mM}-\mathrm{Tris} / \mathrm{HCl}, 1 \mathrm{mM}-\mathrm{MgCl}_{2}, \mathrm{pH} 6.8$, to 
an optical density of 6.5 at $660 \mathrm{~nm}\left(1.76 \mathrm{mg}\right.$ dry weight $\left.\mathrm{ml}^{-1}\right)$, determined by appropriate dilution. Mutanolysin was added to a concentration of 50 units $\mathrm{ml}^{-1}$ and the mixture was incubated overnight at $39^{\circ} \mathrm{C}$. The optical density of the cell suspension decreased by about $90 \%$ following incubation. Remaining cells and cell debris were removed by centrifugation, and the supernatant was stored frozen until required for SDS-PAGE analysis.

SDS-PAGE. This was done according to Laemmli (1970) using $7 \cdot 5 \%(\mathrm{w} / \mathrm{v})$ polyacrylamide gels. Samples were preincubated at $39{ }^{\circ} \mathrm{C}$ for $1 \mathrm{~h}$ in $2 \%(\mathrm{w} / \mathrm{v})$ SDS, $5 \%(\mathrm{w} / \mathrm{v}) 2$-mercaptoethanol before loading on to the gel. The samples were not boiled since it was desired to retain enzyme activity. $M_{\mathrm{r}}$ markers were myosin $\left(M_{\mathrm{r}} 205000\right), \beta$ galactosidase $\left(M_{\mathrm{r}} 116000\right)$, phosphorylase-b $\left(M_{\mathrm{r}} 97400\right)$, BSA $\left(M_{\mathrm{r}} 66000\right)$, ovalbumin $\left(M_{\mathrm{r}} 45000\right)$ and carbonic anhydrase $\left(M_{\mathrm{r}} 29000\right)$, from Sigma. Gels were silver-stained according to the method of Oakley et al. (1980). $M_{\mathrm{r}}$ values were estimated according to Plikaytis et al. (1986).

Gel replica technique for localization of CMCase or xylanase activity. CMCase and xylanase activities were detected in polyacrylamide gels by modification of the method of Beguin (1983). Following SDS-PAGE, the gel was shaken in a solution of $2.5 \%(\mathrm{v} / \mathrm{v})$ Triton X-100 for $30 \mathrm{~min}$. The SDS-PAGE gel was then sandwiched between polyacrylamide gels $(7.5 \%$ polyacrylamide) which contained $0.1 \%$ CMC (CMC 7LP, Hercules Inc., Wilmington, Del., USA) or $0.1 \%$ xylan (Fluka) and $0.2 \mathrm{M}$-sodium phosphate buffer, pH 6.8. The gels were left together at room temperature overnight, after which the substrate-containing gels were stained with Congo red $\left(1 \mathrm{mg} \mathrm{ml}^{-1}\right)$ for $1 \mathrm{~h}$, followed by washing in $1 \mathrm{M}-\mathrm{NaCl}$ until bands became visible.

Determination of bacterial cell surface hydrophobicity. Hydrophobicity was measured by the ability of the cells to bind to hexadecane (Westergren \& Olsson, 1983) as well as by the 'salting out' procedure of Lindahl et al. (1981), with ammonium sulphate concentrations ranging from $0.1 \mathrm{M}$ to $2.5 \mathrm{M}$. Both procedures were carried out in the mineral buffer described earlier.

\section{RESULTS}

\section{Solubilization of cellulose}

The majority of strains of $R$. albus used in this study were originally designated as cellulolytic or non-cellulolytic by measurement of acid production in a culture medium containing filter

Table 1. Cellulose degradation and adhesion to Whatman CFll cellulose powder by strains of R. albus

\begin{tabular}{|c|c|c|c|}
\hline \multirow[b]{2}{*}{ Strain } & \multicolumn{2}{|c|}{ Cellulose solubilized $(\%)$} & \multirow{2}{*}{$\begin{array}{l}\text { Bacteria ad } \\
\text { to Whatma } \\
\text { cellulose p } \\
\mathbf{( \%} \text { of cells }\end{array}$} \\
\hline & $\begin{array}{l}\text { Whatman no. } 6 \\
\text { filter paper }\end{array}$ & $\begin{array}{l}\text { Whatman CFIl } \\
\text { cellulose powder }\end{array}$ & \\
\hline \multicolumn{4}{|l|}{ Cellulolytic } \\
\hline $\mathrm{X} 10 \mathrm{C} 33$ & 82 & 6 & 33 \\
\hline $\mathrm{X} 10 \mathrm{C} 56$ & 99 & 1 & $18 \cdot 0$ \\
\hline X6D60 & 48 & 0 & 13.8 \\
\hline $\mathrm{X} 12 \mathrm{D} 62$ & 79 & 0 & 13 \\
\hline X3D54 & 100 & 3 & 19 \\
\hline $21.09 .6 \mathrm{E}$ & 99 & 20 & 14 \\
\hline $22.08 .6 \mathrm{~A}$ & 99 & 20 & 20 \\
\hline Ce54 & 24 & 1 & 0 \\
\hline $\mathrm{Ce} 63$ & 67 & 23 & 27 \\
\hline 7 & 99 & 7 & 12 \\
\hline 20 & 99 & 2 & 49 \\
\hline 30 & 100 & 7 & 15 \\
\hline AcTF 10 & 100 & 1 & \\
\hline \multicolumn{4}{|l|}{ Non-cellulolytic } \\
\hline $\mathrm{X} 9 \mathrm{C} 63$ & 0 & 0 & \\
\hline X5C54 & 0 & 0 & \\
\hline X6D38 & 1 & 3 & \\
\hline $\mathrm{X} 10 \mathrm{C} 62$ & 0 & 1 & \\
\hline X6D34 & 0 & 0 & \\
\hline X8D60 & 0 & 0 & \\
\hline X9D54 & 0 & 0 & 0 \\
\hline$\times 7 A 62$ & 0 & 0 & \\
\hline $\mathrm{X} 2 \mathrm{~A} 57$ & 1 & 0 & \\
\hline X6E39 & 0 & 3 & \\
\hline B. succinogenes S-85 & 52 & 54 & \\
\hline R. flavefaciens FD-1 & 54 & 9 & \\
\hline
\end{tabular}




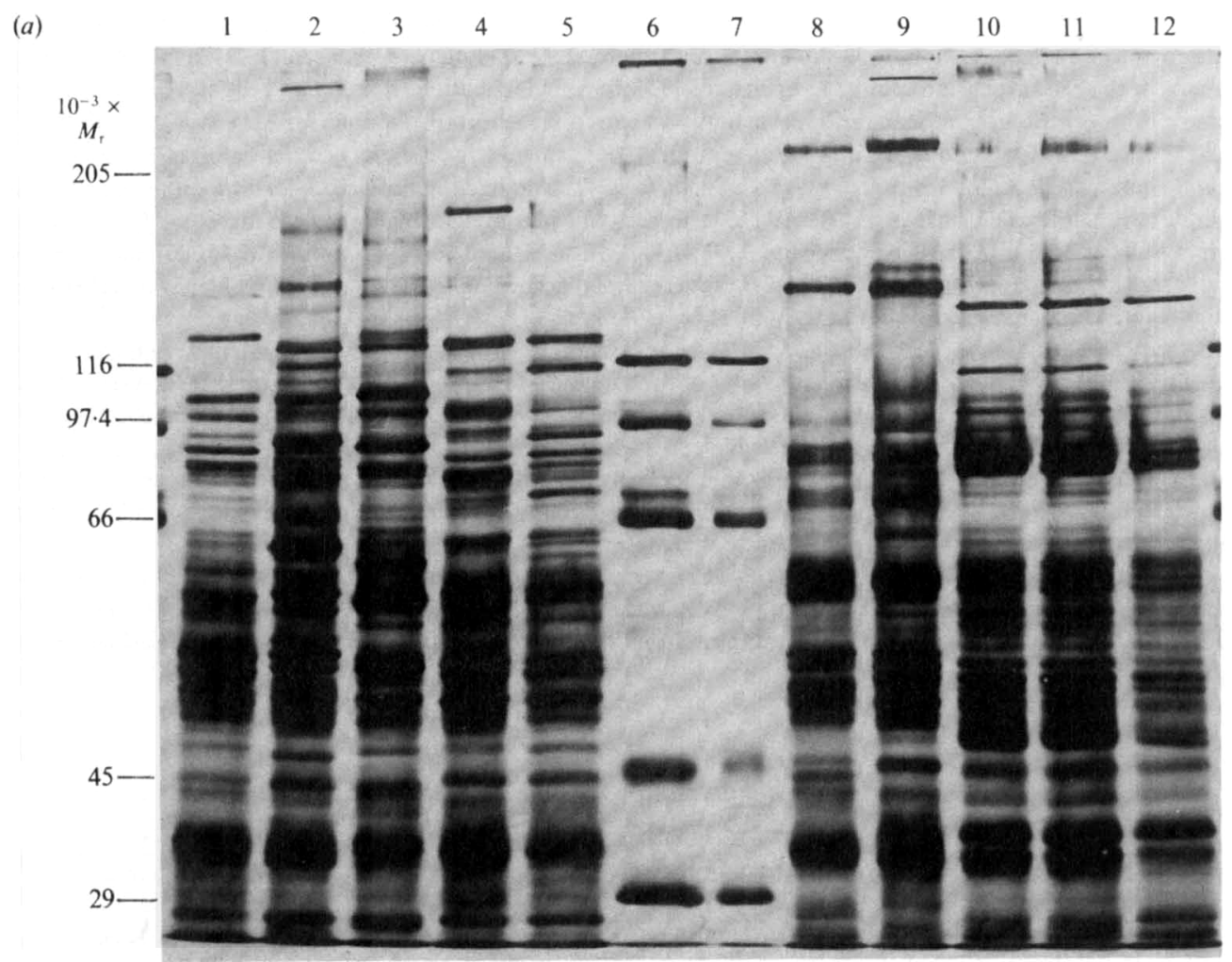

Fig. 1 (continued on facing page). SDS-PAGE of cells of $R$. albus digested with mutanolysin, showing total protein profiles revealed by silver staining $(a)$, CMCase activity $(b)$ and xylanase activity $(c)$. Bands indicated by small, white arrows in $(b)$ and $(c)$ correspond to $M_{\mathrm{r}}$ values given in Table 2. Lanes $1-5$, cellulolytic strains: 1, X10C 33; 2,$20 ; 3$, X6D60;4, X3D $54 ; 5$, X10C 56 . Lanes 6 and 7, $M_{\mathrm{r}}$ markers. Lanes 8-12, non-cellulolytic strains: 8, X9D54; 9, X7A62; 10, X2A57; 11, X6D34; 12, X8D60.

Table 2. Estimated $M_{\mathrm{r}}$ values of CMCase and xylanase activities from SDS-PAGE

\begin{tabular}{lll} 
Strain & \multicolumn{2}{c}{$\overbrace{\text { CMCase }}^{10^{-3} \times M_{\mathrm{r}}}$} \\
Cellulolytic & & \multicolumn{1}{c}{ Xylanase } \\
X10C33 & 56,42 & 72,66 \\
20 & 58,45 & $64,57,44$ \\
X6D60 & $60,57,48$ & $80,67,60,56,47$ \\
X3D54 & $66,55,42$ & 76,54 \\
X10C56 & $66,56,41$ & 79,56 \\
Non-cellulolytic & & \\
X9D54 & 65 & 65,56 \\
X7A62 & 59,46 & $69,59,45$ \\
X2A57 & 59 & 59 \\
X6D34 & 59 & 59 \\
X8D60 & 59 & 59
\end{tabular}


Ruminococcus albus adhesion and cellulolysis

1027

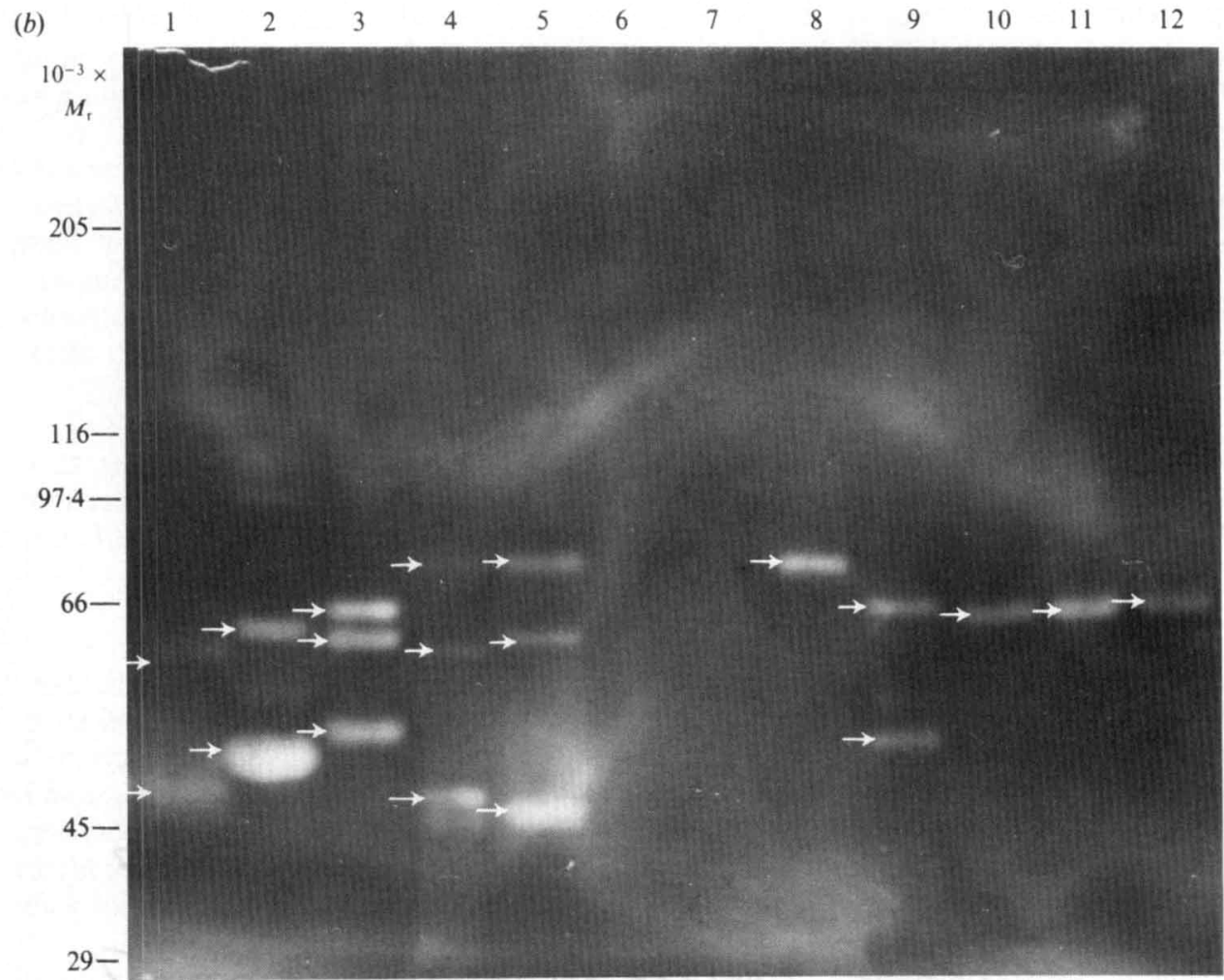

(c)

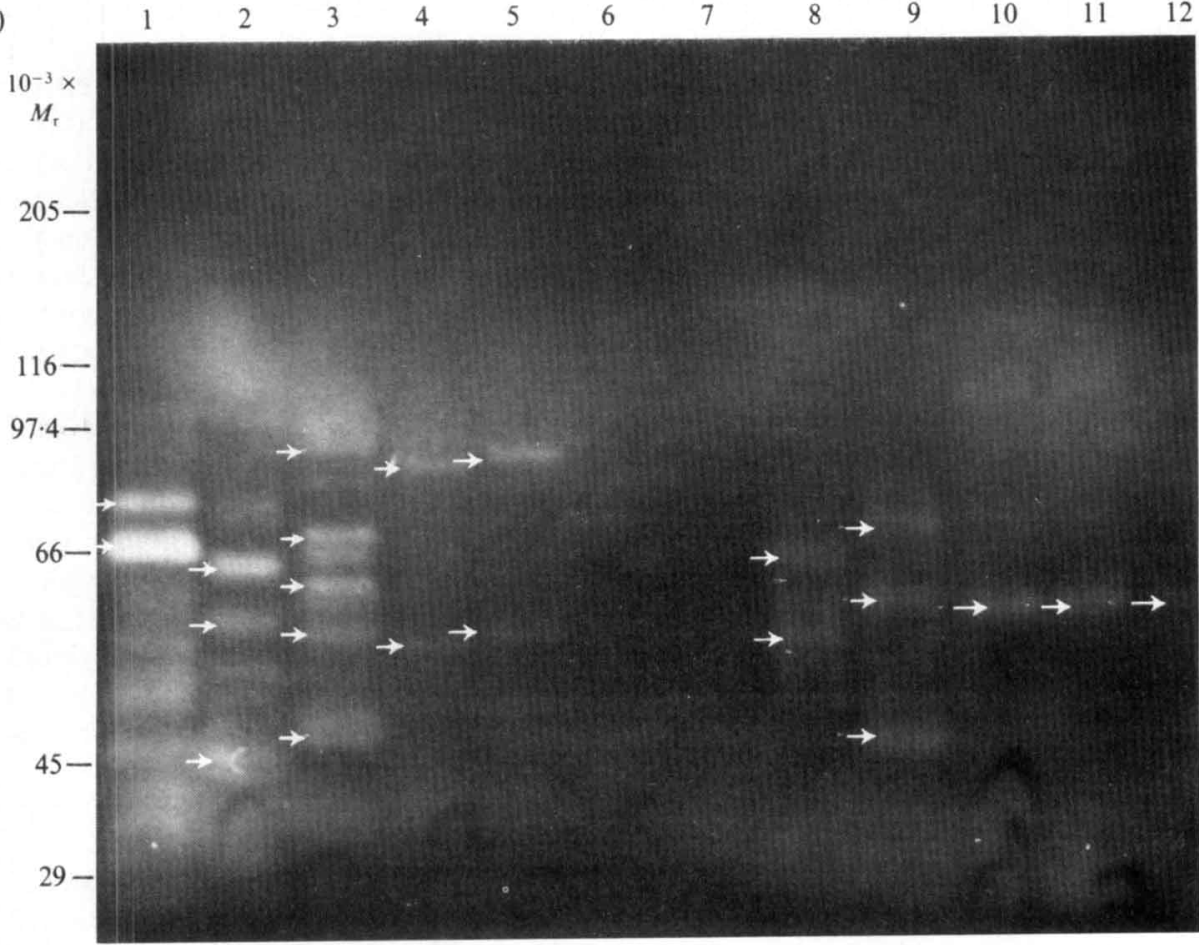


paper cellulose as the sole carbon source. However, for most of the strains nothing was known of the extent of cellulose degradation of which they were capable, nor of their activity on other forms of cellulose such as Whatman CF11, which was used in subsequent adhesion assays. Whatman CF11 is a crystalline cellulose derived from cotton linters.

Measurements were made of the total extent of cellulose solubilization over an incubation period of one week (Table 1). Figures obtained for $B$. succinogenes and $R$. flavefaciens are included for comparison. The strains originally designated as non-cellulolytic did not degrade either filter paper cellulose or CF11 cellulose powder to any significant extent. Among the cellulolytic strains there was considerable variation in the ability to degrade both forms of cellulose, although the CFll cellulose was only poorly attacked by all strains of $R$. albus.

\section{Production of CMCase}

Although the non-cellulolytic strains of $R$. albus did not degrade insoluble cellulose, they all produced significant amounts of CMCase, as demonstrated by the production of colourless zones when colonies grown on agar plates were overlaid with agar containing CMC (data not shown).

\section{Adhesion of $R$. albus to cellulose}

Bacteria were radiolabelled for adhesion assays by inclusion of sodium $\left[1-{ }^{1+} \mathrm{C}\right]$ acetate in the culture medium. In preliminary experiments with [methyl $\left.-1^{\prime}, 2^{\prime}-{ }^{3} \mathrm{H}\right]$ thymidine to label the cells (Morris \& McBride, 1984) no uptake of radioactivity was obtained. Sodium acetate was subsequently selected because Allison \& Bryant (1963) had demonstrated its incorporation into cells of $R$. flavefaciens. Incorporation of radioactivity ranged from 1 to $3 \mathrm{kBq}$ per $\mathrm{mg}$ dry weight of cells. The radionuclide was judged to be stably incorporated into the bacteria since after the first wash almost no radioactivity was found in the supernatant following each subsequent centrifugation step.

Whatman CF11 cellulose powder was chosen for the measurement of adhesion since it settled quickly from suspension and could therefore easily be separated from non-adherent bacteria. Microscopic examination revealed bacteria adhering to the cellulose, with few free cells, demonstrating that the recovered radioactivity was not due to clumps of bacteria settling out with the cellulose. This was confirmed by the fact that radioactivity in control vials (no added cellulose) was low. Preliminary experiments indicated that most of the bacterial adhesion occurred within $5 \mathrm{~min}$ of adding a cell suspension to the cellulose and that little further change occurred after $2 \mathrm{~h}$ incubation. However, $30 \mathrm{~min}$ was taken as a standard incubation period. Adhesion assays were routinely carried out under aerobic conditions as this facilitated experimental procedures. This could be justified since adhesion was not found to be significantly affected by anaerobic conditions, either with or without addition of $1 \mathrm{~mm}$-dithiothreitol. The optimum temperature for adhesion was found to be around $30^{\circ} \mathrm{C}$. However, there was a fairly broad optimum, with little difference between adhesion at $25^{\circ} \mathrm{C}$ (approximate ambient temperature) and at $39^{\circ} \mathrm{C}$. Experiments were therefore conducted at room temperature.

Among the non-cellulolytic strains only X7A62 showed significant adhesion to cellulose (Table 1). Among the cellulolytic strains adhesion ranged from 0 to $49 \%$. However, only two strains (Ce54 and AcTF10) showed less than 10\% adhesion. Within the group of cellulolytic strains there was apparently no correlation between the extent of attachment to CF11 cellulose and the ability to degrade it; for instance strain 20 showed $49 \%$ adhesion but no significant solubilization, while strain $21.09 .6 \mathrm{E}$ showed only $15 \%$ adhesion but solubilized $20 \%$ of the substrate. However, it was of interest that strain Ce54, which did not adhere at all, was also the cellulolytic strain with the least activity on filter paper cellulose.

\section{$S D S-P A G E$ of cell extracts}

Cells of strains of $R$. albus were digested with mutanolysin and the solubilized material was fractionated by SDS-PAGE. Zymograms of CMCase and xylanase activity were obtained by the gel overlay technique. Little protein was visible in SDS-PAGE gels stained with silver nitrate after incubation with substrate-containing gels, suggesting that most of the enzyme 
Table 3. Cell surface hydrophobicity of R. albus determined by aggregation in ammonium sulphate

Results are expressed as the lowest molarity of $\left(\mathrm{NH}_{4}\right)_{2} \mathrm{SO}_{4}$ which gave visible clumping of bacteria when visualized against a dark background and compared with a control [no $\left(\mathrm{NH}_{4}\right)_{2} \mathrm{SO}_{4}$ ].

$\begin{array}{lrcr}\begin{array}{c}\text { Strain } \\ \text { Cellulolytic }\end{array} & \begin{array}{c}\text { Strain } \\ \text { Non-cellulolytic }\end{array} & \text { Hydrophobicity } \\ \text { X10C33 } & & \text { X9C63 } & \\ \text { X10C56 } & \text { ND } & \text { X5C54 } & 2 \cdot 0 \\ \text { X6D60 } & <0 \cdot 1 & \text { X6D38 } & 2 \cdot 0 \\ \text { X12D62 } & 1 \cdot 0 & \text { X10C62 } & 1 \cdot 0 \\ \text { X3D54 } & <0 \cdot 1 & \text { X6D34 } & 2 \cdot 0 \\ 21.09 .6 \mathrm{E} & 0 \cdot 5 & \text { X8D60 } & 1 \cdot 0 \\ 22.08 .6 \mathrm{~A} & 1 \cdot 0 & \text { X9D54 } & 0.5 \\ \text { Ce54 } & 2 \cdot 0 & \text { X7A62 } & 1 \cdot 5 \\ \text { Ce63 } & 2 \cdot 0 & \text { X2A57 } & 0.5 \\ 7 & 1 \cdot 0 & \text { X6E39 } & 1 \cdot 5 \\ 20 & 1 \cdot 5 & & \text { ND } \\ 30 & 1 \cdot 0 & & \\ \text { AcTF10 } & 2 \cdot 5 & & \end{array}$

ND, Not determined.

activity had diffused into the gel overlay. Fig. 1 shows both the total protein profiles as visualized by silver staining and the location of enzyme activity for five cellulolytic and five noncellulolytic strains selected at random. The estimated $M_{\mathrm{r}}$ values of some major bands possessing enzyme activity are given in Table 2 . The cellulolytic strains all possessed a number of bands with CMCase and xylanase activity, but there were marked differences between strains both in the location of these bands and in the total protein profiles (Fig. 1 a). Cellulolytic strains not shown in Fig. 1 also varied considerably both in their protein profiles and in the position of bands with enzyme activity. Certain strains did however show similarities. Strains X3D54 and X10C56 were similar (Fig. 1) and there was also some correspondence between 21.09.6E and 22.08.6A as well as between 30 and AcTF10.

The non-cellulolytic strains had fewer CMCase and xylanase bands, and there was less variation between strains. Of the strains shown in Fig. 1, X2A57, X6D34 and X8D60 had very similar enzyme and protein profiles. These strains appeared to be part of a larger group which included X9C63, X5C54 and X6D38. Strain X7A62 (the only non-cellulolytic strain to show some adhesion) had a somewhat different protein profile from the other strains in this group and possessed an additional band of enzyme activity (Fig. 1). The remaining non-cellulolytic strains (X9D54, X6E39 and X10C62) formed a second group with similar enzyme and protein profiles.

For the non-cellulolytic strains there was good correlation between the positions of bands with CMCase activity and bands with xylanase activity, suggesting that the same enzyme had activity against both substrates. In contrast, for the cellulolytic strains several of the CMCase bands did not correspond with zones of xylanase activity, while a variety of xylanase bands did not have counterparts in the CMC gel. Enzyme activities in mutanolysin digests stored at $-20{ }^{\circ} \mathrm{C}$ were stable for a few weeks, but some changes in band patterns were seen after storage for longer periods.

\section{Cell surface hydrophobicity}

All strains of $R$. albus were completely hydrophilic by the hexadecane binding assay as practically all the cells remained in the aqueous layer. The ammonium sulphate 'salting out' procedure did reveal some differences between strains (Table 3). However, there was no apparent correlation between the ammonium sulphate concentration required for the clumping reaction and the ability of the strains to adhere to cellulose (Table 1). 


\section{DISCUSSION}

The development of an assay using radiolabelled cells to measure adhesion to cellulose has enabled an assessment to be made of the relative abilities of strains of $R$. albus to adhere to cellulose. Although Latham et al. (1979) refer to the use of ${ }^{14} \mathrm{C}$-labelled bacteria to measure adhesion of rumen bacteria to plant stems, this is believed to be the first complete account of such an assay.

The results demonstrate a relationship between the ability to adhere to CF11 cellulose and the ability to degrade filter paper. However, there was no correlation between adhesion and solubilization of CF11 cellulose, since many of the adherent strains were unable to degrade this substrate. Thus it seems that adhesion is not necessarily followed by cellulolysis. It appears from the results obtained here that strains which cannot adhere produce only limited cellulolysis. In contrast Kauri \& Kushner (1985) found that for a variety of bacteria, degradation of cellulose did not depend on cell-fibre contact. Unfortunately none of the rumen bacteria were included in their study. As pointed out by Wood \& Wilson (1984), cell-free enzyme extracts are often not as effective as the whole cells in degrading cellulose, demonstrating that some essential factor present on the bacterium is missing in the cell-free extract.

It is not clear at present whether the non-adherent strains of $R$. albus are unable to bind to cellulose because of the lack of specific 'adhesion factor' or 'affinity factor' as proposed by Leatherwood (1969), as a result of which cell-associated enzymes cannot come into contact with their substrate, or alternatively whether the lack of particular cellulolytic enzymes capable of binding to the insoluble substrate in itself prevents adherence. If adhesion is mediated by cellulases, then endocellulases, $\beta$-glucosidases (cellobiases) or exocellulases (if present) could be responsible. Wood \& Wilson (1984) found no evidence for exocellulase production by $R$. albus. In the work described in this paper the possible role of endocellulases in adhesion was studied. Examination of the endocellulase (CMCase) activity produced by adherent (cellulolytic) and non-adherent (non-cellulolytic) strains grown on agar plates and overlaid with agar containing CMC revealed production of CMCases by all strains. However, in the context of adhesion it was important to know whether such enzymes were bound to the cell surface or whether they were secreted into the culture medium. Washed bacterial cells were therefore solubilized by digestion with mutanolysin. It is presumed that cellulase and xylanase activities released in this way are located on the cell surface, since it is unlikely that polysaccharide-degrading enzymes would have an intracellular location. The solubilized material was fractionated by SDS-PAGE and enzyme activity was located in the gels using a zymogram technique. All the cellulolytic and noncellulolytic strains tested possessed cell-associated CMCases and xylanases, although the noncellulolytic strains clearly had fewer bands of activity than the cellulolytic strains. The fact that the non-cellulolytic (and non-adherent) strains possess cell-associated CMCase activity does not however rule out the possibility that this activity could mediate adherence. It has recently been shown for fungal cellulases (Hayashida \& Mo, 1986; Klyosov et al., 1986) that while a variety of endoglucanases are able to degrade soluble cellulosic derivatives, not all such enzymes have the ability to bind to insoluble cellulose. Such binding ability might constitute the ' $C_{1}$ ' activity supposedly required for hydrolysis of highly ordered celluloses (Reese et al., 1950).

Several workers have identified a large cellulase complex on the surface of $R$. albus (Stack \& Hungate, 1984, 1985; Wood et al., 1982). Such a complex might correspond to the 'cellulosome' of $C$. thermocellum (Bayer et al., 1985) and could be expected to contain the full complement of enzyme and adhesive activities. Any alteration in one component of such an aggregate might affect the total cellulolytic activity, as well as affecting the adhesive ability of the complex. Wood et al. (1982) found that much of the high- $M_{\mathrm{r}}$ complex was removed from the cell surface by washing with a high-ionic-strength buffer. We have also found some enzyme released in this way. To minimize enzyme release, the cells were washed briefly (twice only) in a fairly low-ionicstrength buffer before digestion with mutanolysin. Zymograms obtained after mutanolysin digestion indicated that considerable enzyme activity was retained on the cell surface, and the range of $M_{\mathrm{r}}$ values corresponds well with those produced by disaggregation of the high- $M_{\mathrm{r}}$ complex (Wood et al., 1982).

The multiplicity of enzyme activities revealed in the zymograms could be partially the result of incomplete denaturation, since the samples were not pre-boiled. For this reason, and because 
the $M_{\mathrm{r}}$ markers are not visible on zymograms, the $M_{\mathrm{r}}$ values given in Table 2 may be inaccurate. However, each organism produced a characteristic zymogram in repeated experiments. The enzyme activities seen do not necessarily represent the full complement of endoglucanases and xylanases, since only those activities which are renaturable after treatment with SDS will show activity on the zymogram.

Marked differences between strains were apparent in the SDS-PAGE protein profiles (Fig. $1 a$ ) and in the zymograms (Fig. $1 b, c$ ). All the strains produced fermentation end products characteristic of $R$. albus, but it is possible that they may not be closely related. Jarvis (1967) found considerable serological diversity amongst organisms of the genus Ruminococcus.

Anaerobic conditions did not appear to stimulate adhesion of $R$. albus. This was of interest since Smith et al. (1973) previously demonstrated that cellulolysis in $R$. albus was partially inhibited by oxygen. They interpreted this as a complete inhibition of one or more, but not all, of the enzymes. The lack of oxygen sensitivity in adhesion to cellulose cannot however be taken as a general rule since Kopecny et al. (1983) found that adhesion of mixed rumen micro-organisms was markedly stimulated by addition of dithiothreitol.

In contrast with many other biological systems (Edebo et al., 1980), no correlation was found between bacterial adhesion and the possession of a hydrophobic cell surface. This was perhaps not surprising since it is not to be expected that hydrophobic interactions would play a role in adhesion to a hydrophilic substrate such as cellulose. Jones and Isaacson (1983) have stressed the need to use several procedures in evaluating adhesin hydrophobicity. In this instance all strains were hydrophilic by the hexadecane assay, but differences between strains could be seen by using the ammonium sulphate technique. However, these differences may be indicative of variations in surface components unrelated to those which mediate adhesion. In this context Fives-Taylor \& Thompson (1985) found that while the majority of non-adherent mutants of Streptococcus sanguis had a decreased hydrophobicity, some in fact showed an increase in hydrophobicity.

Work is currently in progress to further characterize the cell surfaces of these bacteria, with the aim of identifying specific molecules responsible for adhesion.

The authors thank the Director of the Veterinary Research Institute, Onderstepoort, for the use of facilities which made this work possible. Thanks are due to Mrs D. N. Barry, Mr H. Mohloare and Mr M. Ndlovu for valuable technical assistance.

\section{REFERENCES}

AKIN, D. E. (1980). Evaluation by electron microscopy and anaerobic culture of types of rumen bacteria associated with digestion of forage cell walls. Applied and Environmental Microbiology 39, 242-252.

AKIN, D. E., Burdick, D. \& Michaels, G. E. (1974). Rumen bacterial interrelationships with plant tissue during degradation revealed by transmission electron microscopy. Applied Microbiology' 27, 11491156.

Allison, M. J. \& BRyANT, M. P. (1963). Biosynthesis of branched-chain amino acids from branched-chain fatty acids by rumen bacteria. Archives of Biochemistry and Biophysics 101, 269-277.

Bayer, E. A., Kenig, R. \& Lamed, R. (1983). Adherence of Clostridium thermocellum to cellulose. Journal of Bacteriology 156, 818-827.

Bayer, E. A., Setter, E. \& Lamed, R. (1985). Organization and distribution of the cellulosome in Clostridium thermocellum. Journal of Bacteriology 163, 552-559.

Beguin, P. (1983). Detection of cellulase activity in polyacrylamide gels using Congo red-stained agar replicas. Analytical Biochemistry 131, 333-336.

Bryant, M. P., Small, N., Bouma, C. \& Robinson, I. M. (1958). Characteristics of ruminant anaerobic cellulolytic cocci and Cillobacterium cellosolvens $\mathbf{n} . \mathbf{s p}$. Journal of Bacteriology 76, 529-537.

Caldwell, D. R. \& Bryant, M. P. (1966). Medium without rumen fluid for nonselective enumeration and isolation of rumen bacteria. Applied Microbiology 14, 794-801.

Edebo, L., Kihlstrom, E., Magnusson, K. E. \& Stendahl, O. (1980). The hydrophobic effect and charge effects in the adhesion of enterobacteria to animal cell surfaces and the influences of antibodies of different immunoglobulin classes. In Cell Adhesion and Mobility, Third Symposium of the British Society for Cell Biology, pp. 65-101. Edited by A. S. G. Curtis \& J. D. Pitts. Cambridge: Cambridge University Press.

Fives-Taylor, P. M. \& Thompson, D. W. (1985). Surface properties of Streptococcus sanguis FW 213 mutants nonadherent to saliva-coated hydroxyapatite. Infection and Immunity 47, 752-759.

vaN GylswYK, N. O. \& Hoffman, J. P. L. (1970). Characteristics of cellulolytic cillobacteria from the rumens of sheep fed teff (Eragrostis tef) hay diets. Journal of General Microbiology 60, 381-386.

van Gylswyk, N. O. \& Roche, C. E. G. (1970). Characteristics of Ruminococcus and cellulolytic 
Butyrivibrio species from the rumens of sheep fed differently supplemented teff (Eragrostis tef) hay diets. Journal of General Microbiology 64, 11-17.

HaYashida, S \& Mo, K. (1986). Production and characteristics of avicel-disintegrating endoglucanase from a protease-negative Humicola grisea var. thermoidea mutant. Applied and Environmental Microbiology 51, 1041-1046.

HeNNING, P. A. (1979). Examination of methods for enumerating hemicellulose-utilizing bacteria in the rumen. Applied and Environmental Microbiology 38. 13-17.

JARVIS, B. D. W. (1967). Antigenic relations of cellulolytic cocci in the sheep rumen. Journal of General Microbiology 47, 309-319.

Jones, G. W. \& IsAaCson, R. E. (1983). Proteinaceous bacterial adhesins and their receptors. CRC Critical Reviews in Microbiology 10, 229-260.

KAURI. T. \& KuShNER, D. (1985). Role of contact in bacterial degradation of cellulose. FEMS Microbiology' Ecology 31, 301-306.

Kistner, A. \& Gouws, L. (1964). Cellulolytic cocci occurring in the rumen of sheep conditioned to lucerne hay. Journal of General Microbiology 34, 447 458.

Klyosov, A. A., Mitkevich, O. V. \& Sinitsyn, A. P. (1986). Role of the activity and adsorption of cellulases in the efficiency of the enzymatic hydrolysis of amorphous and crystalline cellulose. Biochemistry 25, 540-542.

Kopecny, J., JuRCUK, J. F. \& Bartos, S. (1983). The effect of $\mathrm{pH}$ and 1,4-dithiothreitol on the adhesion of rumen bacteria. Folia microbiologica 28, 130-133.

LAEMMLI, U. K. (1970). Cleavage of structural proteins during the assembly of the head of bacteriophage T4. Nature, London 227, 680-685.

Lamed, R., Setter, E. \& Bayer, E. A. (1983). Characterization of a cellulose-binding, cellulasecontaining complex in Clostridium thermocellum. Journal of Bacteriology 156, 828-836.

latham, M. J., Brooker, B. E., Pettipher, G. L. \& HARRIS, P. J. (1978). Adhesion of Bacteroides succinogenes in pure culture and in the presence of Ruminococcus flavefaciens to cell walls in leaves of perennial ryegrass (Lolium perenne). Applied and Environmental Microbiology 35, 1166-1173.

Latham, M. J., Hobbs, D. G. \& Harris, P. J. (1979). Adhesion of rumen bacteria to alkali-treated plant stems. Annales de recherches vétérinaires 10, 244-245.

LEATHERWOOD, J. M. (1969). Cellulase complex of Ruminococcus and a new mechanism for cellulose degradation. In Cellulases and Their Applications, Advances in Chemistry Series vol. 95, pp. 53-59. Edited by G. J. Hajny \& E. T. Reese. Washington, DC: American Chemical Society.

Lindahl, M., Faris, A., Wadstrom, T.\& HJerten, S. (1981). A new method based on 'salting out' to measure relative surface hydrophobicity of bacterial cells. Biochimica et biophysica acta 677, 471-476.

Minato, H. \& Suto, T. (1978). Technique for fractionation of bacteria in rumen microbial ecosystem. II. Atttachment of bacteria isolated from bovine rumen to cellulose powder in vitro and elution of bacteria attached therefrom. Journal of General and Applied Microbiology 24, 1-16.
MorRIS, E. J. \& VAN GyLSWYK, N. O. (1980). Comparison of the action of rumen bacteria on cell walls from Eragrostics tef. Journal of Agricultural Science 95, 313-323.

Morris, E. J. \& McBride, B. C. (1984). Adherence of Streptococcus sanguis to saliva-coated hydroxyapatite: evidence for two binding sites. Infection and Immunity 43, 656-663.

OAKLEY, B. R., KIRSCH, D. R. \& MORRIS, N. R. (1980). A simplified ultrasensitive silver stain for detecting proteins in polyacrylamide gels. Analytical Biochemistry 105, 361-363.

Patterson, H., Irvin, R., Costerton, J. W. \& CHENG, K. J. (1975). Ultrastructure and adhesion properties of Ruminococcus albus. Journal of Bacteriology 122, 278-287.

Plikaytis, B. D., Carlone, G. M., Edmonds, P. \& MAYER, L. W. (1986). Robust estimation of standard curves for protein molecular weight and linearduplex base-pair number after gel electrophoresis. Analytical Biochemistry 152, 346-364.

Reese, E. T., SiU, G. H. \& Levinson, H. S. (1950). The biological degradation of soluble cellulosic derivatives and its relation to the mechanism of cellulose hydrolysis. Journal of Bacteriology 59, 485-497.

Shane, B. S., Gouws, L. \& Kistner, A. (1969). Cellutolytic bacteria occurring in the rumen of sheep conditioned to low-protein teff hay. Journal of General Microbiology 55, 445-457.

SMIth, W. R., YU. I. \& Hungate, R. E. (1973). Factors affecting cellulolysis by Ruminococcus albus. Journal of Bacteriology 114, 729-737.

StaCk, R. J. \& Hungate, R. E. (1984). Effect of 3phenylpropanoic acid on capsule and cellulases of Ruminococcus albus 8. Applied and Environmental Microbiology 48, 218-223.

Stack, R. J. \& Hungate, R. E. (1985). Biochemical properties of the cellulase complex $0^{f}$ Ruminococcus albus. Abstracts of the Annual Meeting of the American Society for Microbiology 85, K 129.

TEATher, R. M. \& WoOD, P. J. (1982). Use of Congo red-polysaccharide interactions in enumeration and characterization of cellulolytic bacteria from the bovine rumen. Applied and Environmental Microbiology 43, 777-780.

VAN DER TOORN, J. J. T. K. \& VAN GyLSWYK, N. O. (1985). Xylan-digesting bacteria from the rumen of sheep fed maize straw diets. Journal of General Microbiology 131, 2601-2607.

Westergren, G. \& Olsson, J. (1983). Hydrophobicity and adherence of oral streptococci after repeated subculture in vitro. Infection and Immunity 40, 432435.

WoOD, T. M. \& WILSON, C. A. (1984). Some properties of the endo-(1-4)- $\beta$-glucanase synthesized by the anaerobic cellulolytic rumen bacterium Ruminococcus albus. Canadian Journal of Microbiology 30, 316321.

Wood, T. M., Wilson, C. A. \& Stewart, C. S. (1982). Preparation of the cellulase from the cellulolytic anaerobic rumen bacterium Ruminococcus albus and its release from the bacterial cell wall. Biochemical Journal 205, 129-137. 